\title{
Spatial and vertical biogeography of coral reef sediment bacterial and diazotroph communities
}

\author{
Ian Hewson ${ }^{1,2, *}$, Jed A. Fuhrman ${ }^{1}$ \\ ${ }^{1}$ Wrigley Institute for Environmental Studies, Department of Biological Sciences, University of Southern California, \\ 3616 Trousdale Parkway AHF 107, Los Angeles, California 90089-0371, USA \\ ${ }^{2}$ Present address: Department of Ocean Sciences, University of California Santa Cruz, 1156 High Street EMS D446, \\ Santa Cruz, California 95064, USA
}

\begin{abstract}
Coral reefs are globally important marine ecosystems as sites of high biotic diversity. Reef flat sediments are reasonably homogeneous in composition. This substratum is subject to gradients in water motion, grazing pressure and benthic productivity. This study used DNA fingerprinting techniques, automated rRNA intergenic spacer analysis (ARISA), and terminal restriction fragment length polymorphism (TRFLP) to examine patterns of bacterial assemblage composition within Heron Reef flat sediments, targeting the entire bacterial community (not including Archaea) and nitrogenfixing bacteria. ARISA fingerprints contained between 51 and 148 operational taxonomic units (OTU) per surface sediment sample. The mean whole-community similarity between adjacent sites along a transect from Heron Island to the reef crest was $0.50 \pm 0.03$ (mean \pm SE) Whittaker Index (comparison of relative abundances) and $0.46 \pm 0.03$ Jaccard Index (presence/absence only). Comparison of sediment community fingerprints to a water column community fingerprint collected above the reef flat at high tide indicated that sediments contained different assemblages to the water column (mean similarity between sediments and water column assemblage $=0.15 \pm 0.01$ Jaccard Index); however, assemblage composition did not differ significantly from that expected by random association. Vertical sediment cores showed dissimilarity between surface (0 to $3 \mathrm{~cm}$ ) and deep (3 to $5 \mathrm{~cm}$ ) community fingerprints, which was probably related to redox state. Comparison of fingerprints of fecally-derived sediments from the sea cucumber Holothuria atra and surrounding sediments indicated that the impact of metazoan grazing could not be distinguished from ambient small spatial scale variability in sediment assemblage composition. The nifH-TRFLP fingerprints of sediment prokaryotic assemblages (amplified from all samples, but only in sufficient quantities for analysis from 7 locations) indicated the presence of ubiquitous, potentially diverse diazotroph communities, with little assemblage similarity between locations. Our results suggested that while bacterial assemblages (including communities of nitrogen-fixing bacteria) in sediments of a coral reef are diverse, their assemblage composition is not related to grazing pressure but may be influenced by other biotic and abiotic environmental conditions such wave energy and sediment depth.
\end{abstract}

KEY WORDS: Coral reefs · Bacteria $\cdot$ Disturbance $\cdot$ Diversity $\cdot$ Holothuria atra

Resale or republication not permitted without written consent of the publisher

\section{INTRODUCTION}

Coral reefs are marine habitats of high biotic diversity and are among the most productive ecosystems on earth. Most studies of diversity in coral reefs have focused on the biogeography of macroorganisms, e.g. scleractinian corals and macroalgae (Glynn 1976), and the impact of human activities on coral reef ecosystems (Hughes et al.
2003). Prokaryotic (Bacterial and Archaeal) assemblages associated with coral tissue surfaces are abundant, extremely diverse (e.g. Rohwer et al. 2002), and within sediments are productive (Rasheed et al. 2004, Wild et al. 2004). Sediments in coral reefs contain large biomasses of microalgal chlorophyll a (Heil et al. 2004), and nitrogen fixation has been measured within coral sediments in at least 1 study (Capone 1996), suggesting that coral 
reef atolls and reef flats are active sites of biogeochemistry relative to chlorophyll-poor surrounding waters. Despite the biogeochemical importance of reef flat sediments in the oligotrophic ocean, there have been no previous studies to examine spatial patterns of sediment bacterial assemblages.

Microbial diversity in the ocean has been studied from several perspectives that have targeted ecological and biogeochemical sources of variation in community structure (Giovannoni et al. 1990, Fuhrman \& Davis 1997, Venter et al. 2004). Early studies examining the diversity of bacteria in soils demonstrated that the same bacteria could be identified in enrichment cultures of geographically distant samples, which led to the maxim that 'everything is everywhere' and 'the environment selects' (Beijerinck 1913). The former of these ideas has not been tested in the marine environment, but observation of phylogenetically-close relatives of SAR-11 group bacteria at diverse global locations (Morris et al. 2002), novel candidate divisions of deep sediment bacteria at widespread sites (Webster et al. 2004), and closely related Group I Archaea in mesopelagic waters of the North Atlantic and Pacific (Fuhrman \& Davis 1997) suggests some overlap of at least similar species in extremely widespread locations. Selection leading to particular bacterial assemblages has not been adequately addressed in marine sediments, but environmental specificity of bacterioplankton assemblage composition has been previously investigated in estuaries (Hewson \& Fuhrman 2004), and metazoan specificity of coral surface-associated bacteria in geographically distant locations has been observed (Rohwer et al. 2002). The hypothesis that similar environmental conditions select for similar assemblage structures can be easily examined in marine sediments. Marine sediments are thought to be heterogenous and patchy habitats, characterised by micrometer- to millimeter-scale geochemical gradients. However, sediments on coral reef flats can have remarkably deep but variable (i.e. 1 to $3 \mathrm{~cm}$ ) oxic layers (Rasheed et al. 2004), experience similar levels of radiative energy flux, are of remarkably consistent geological composition, and are relatively immobile in space and time. Little is known of sediment microbial assemblage patterns and dynamics, nor the factors controlling them.

Two types of scientific investigation provide insight into factors shaping biological diversity. The first of these is observation of communities over natural gradients, while the second is direct manipulative experimentation. Since bacteria are subject to significant bottle effects during containment (Hewson et al. 2003), experimental manipulation is not ideal for examining ecological interactions within sediments if the time required to observe experimental effects exceeds the time within which bacteria will be influenced by con- tainment. In contrast, observation of environmental gradients in bacterial diversity allows inference of community dynamics in response to environmental stimuli. In the absence of significant trophic gradients (and hence differences in resource availability), factors shaping coral reef sediment microbial communities that co-vary with trophic conditions in other environments (e.g. estuaries) can be examined independently. Due to relatively consistent illumination and chemical inputs across reef flats, gradients result from physical energy flux (and concomitant disturbance) and biological reworking by macrofauna, which in turn causes increased oxygen flux (via bioturbation and bioirrigation) and input of fecal materials. Irradiative flux to the sea surface is constant across the reef flat, but varies locally in the benthos as punctuated by coral and algal cover.

The aim of this study was to identify geographical patterns in bacterial and diazotroph assemblages in unconsolidated sediments, and to discuss their potential relation to environmental gradients on the Heron Reef flat. This study examined sediments on the Heron Reef flat, a coral cay of 28 ha on the southern Great Barrier Reef, Australia, which exhibits the characteristic coral zonation of coral cays worldwide (Glynn 1976). Diversity of scleractinian corals has been investigated on this reef over the past 3 decades, which has led to classical ecological hypotheses such as those by Connell (1978). This reef is also one of the loci of research on the effects of global warming upon coral reef bleaching (Hughes et al. 2003). To examine sediment bacterial communities in this ecosystem, we used 2 culture-independent fingerprinting approaches that offer high resolution at both total and functional group levels: (1) automated rRNA intergenic spacer analysis (ARISA) (Fisher \& Triplett 1999), which amplifies 16S-23S rRNA internally transcribed spacer (ITS) DNA fragments, was used to examine total bacterial community structure, and (2) terminal restriction fragment length polymorphism (TRFLP) of a portion of the nifHDK operon was used to a analyze nitrogen-fixing functional group composition (Widmer et al. 1999). These techniques allow observation of clear differences in assemblage composition among samples; although they can also be used to provide identification of organisms, this application requires clone libraries of 16S rRNA and nifH genes (Brown et al. 2005), which have not yet been compiled for our study environment.

\section{MATERIALS AND METHODS}

Sample collection. All samples were collected in early January 2003 on the Heron Island Reef Flat,

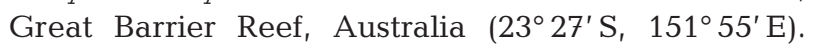
Samples were collected at low tide along a $140 \mathrm{~m}$ tran- 
sect from Heron Island to the reef crest every $20 \mathrm{~m}$ (Fig. 1). When referring to sample location along the transect line, $0 \mathrm{~m}$ hereby denotes the reef crest and -140 m denotes the sample location adjacent to Heron Island. Small-scale spatial variability was also determined by collecting duplicate samples within a $10 \mathrm{~cm}^{2}$ sediment patch in Shark Bay. Sediment samples were collected at low tide using a $10 \mathrm{ml}$ syringe with the needle end removed. The plunger on the sediment corer was placed flat on the sediment surface and barrel pushed into sediments to a depth of $1.2 \mathrm{~cm}$, thus enclosing $1 \mathrm{~cm}^{3}$ of sediment. The syringe corer was then withdrawn and sediments extruded into $15 \mathrm{ml}$ sterile centrifuge tubes. Vertical profile samples were collected in the same way, but to a depth of $5 \mathrm{~cm}$, and the entire sediment core was sectioned at $1 \mathrm{~cm}$ intervals using a sterile razor blade. To investigate the effects of holothurian grazing upon sediment bacterial communities, we collected (1) sediments immediately

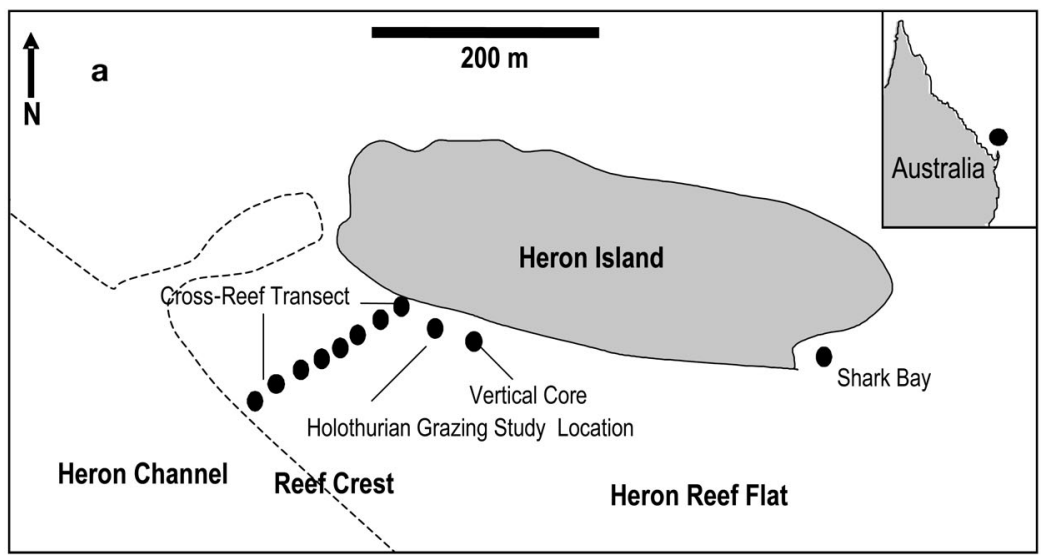

b
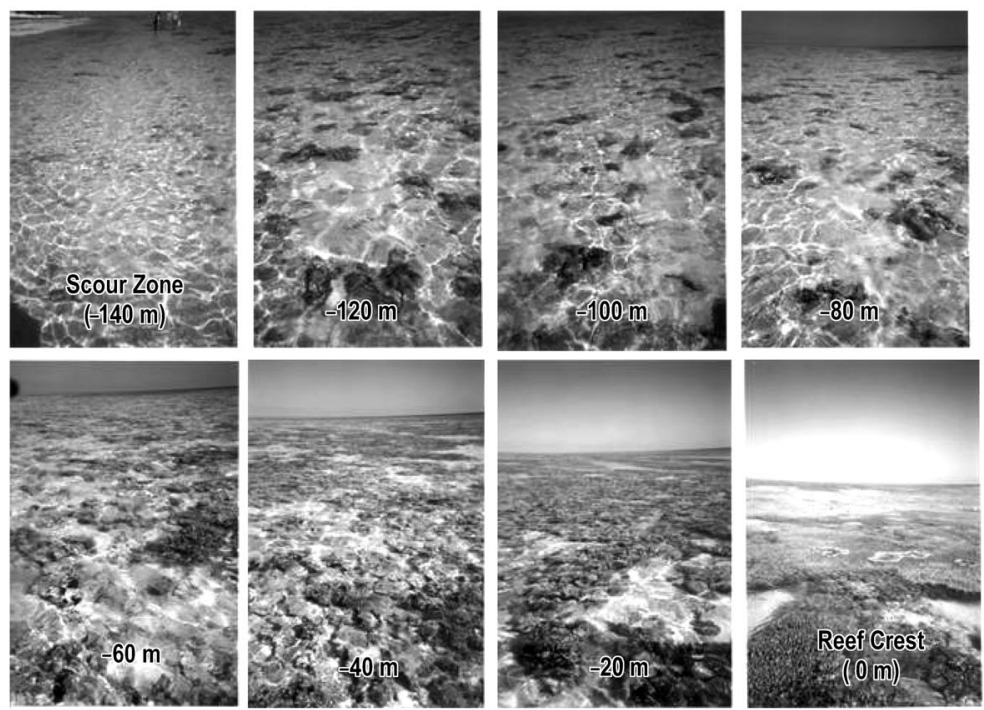

Fig. 1. (a) Sampling location on Heron Island (Great Barrier Reef, Australia) showing cross-reef transect sampling sites, holothurian grazing study sites, vertical core site and Shark Bay site. (b) Eight transect locations demonstrating change in coral cover in front of Holothuria atra (i.e. within $2 \mathrm{~cm}$ of an animal's mouth), and (2) semi-consolidated fecal pellets immediately behind the animal. To investigate water column bacterial communities, 201 of surface water was collected from the reef flat at high tide using an acid- and seawater-rinsed low density polyethylene cubitainer. Surface water was subsequently filtered over a $47 \mathrm{~mm} \mathrm{~A} / \mathrm{E}$ Glass Fiber Filter (1.2 $\mu \mathrm{m}$ nominal pore size) to remove metazoa and algae, and then over a $0.2 \mu \mathrm{m}$ Durapore (Millipore Corp Type GVWP) filter to collect bacterial DNA. All samples were maintained at $-80^{\circ} \mathrm{C}$ prior to laboratory analysis at the University of Southern California.

DNA extraction. Sediment subsamples, holothurian fecal pellets, and the water column Durapore filter were extracted using BIO101 Soil DNA extraction kits (QBIOGENE), where DNA was eluted in a final extracted volume of $50 \mu \mathrm{l}$. DNA was quantified using PICO Green Fluorescence (Molecular Probes) on a Stratagene MX3000 quantitative fluorometer. For the water column filter, the initial agitation step with lysing matrix was replaced by placing the folded filter filtration-side out into an eppendorf tube and boiling for $60 \mathrm{~s}$ in the presence of buffer PBR and MT (manufacturersupplied reagents).

Microbial community fingerprinting. ARISA was conducted on $10 \mathrm{ng}$ extracted DNA as measured by Pico Green (Molecular Probes) fluorescence (Fisher \& Triplett 1999) with modifications as described previously (Hewson et al. 2003). The ITS region (plus 285 bases of $16 \mathrm{~S}$ and $23 \mathrm{~S}$ rRNA) of DNA extracts was amplified using the polymerase chain reaction (PCR). PCR was carried out in $50 \mu \mathrm{l}$ reactions using $1 \times$ PCR buffer (Promega), $2.5 \mathrm{mM} \mathrm{MgCl}_{2}$ (Promega), $250 \mu \mathrm{M}$ of each deoxynucleotide (Promega), $200 \mathrm{nM}$ each of universal primer $16 \mathrm{~s}-1392 \mathrm{~F} \quad\left(5^{\prime}-\mathrm{G}(\mathrm{C} / \mathrm{T})\right.$ ACACACCGCCCGT-3') and bacterial primer 23s-125R labeled with a 5' TET (5' - GGGTT(C/G/T)CCCCATTC(A/G)G- 3'), 2.5 U Taq polymerase (Promega) and BSA (40 ng $\mathrm{ll}^{-1}$ final concentration, Sigma \#A-7030). These primers specifically targeted bacteria, hence archaea are not included in our analysis. Thermocycling was preceded by a $3 \mathrm{~min}$ heating step at $94^{\circ} \mathrm{C}$, followed by 30 denaturing cycles at $94^{\circ} \mathrm{C}$ for $40 \mathrm{~s}$, annealing at $55^{\circ} \mathrm{C}$ for $40 \mathrm{~s}$, extension at $72^{\circ} \mathrm{C}$ for $90 \mathrm{~s}$, with a final extension step 
of 5 min at $72^{\circ} \mathrm{C}$. The calculated melting temperatures of both primers were approximately $52^{\circ} \mathrm{C}$. PCR amplification products were purified in Zymo Clean \& Con-

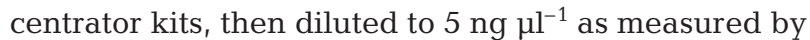
Pico Green fluorescence.

TRFLP was conducted on nifH gene fragments on $20 \mathrm{ng}$ extracted DNA as described previously (Widmer et al. 1999). Nested amplification of nifH gene fragments using degenerate primers comprised 2 steps (Zehr et al. 1998). Amplification consisted of the same thermocycling protocol and contained identical PCR reagent mixtures as ARISA amplification. For the first amplification step, PCR primers nifH3 (5'-ATRTTRTTNGCNGCRTA-3') and nifH4 (5'-TTYTAYGGNAARGGNGG-3') were used. PCR products $(4 \mu \mathrm{l})$ from the first round of amplification were then transferred to a new reaction and re-amplified using the nested degenerate primers nifH1 (5'-TET-TGYGAYCCNAARGCNGA-3') and nifH2 (5'-ANDGCCATCATYTCNCC-3'), where TET indicated the fluorochrome labeled primer. PCR products were run on 1\% SeaKem GTC Agarose Gels $(1 \times \mathrm{TBE})$ at $100 \mathrm{~V}$ for $1 \mathrm{~h}$, and gels were poststained with SYBR Gold $\left(1 \mu \mathrm{ml}^{-1}\right.$ of manufacturer's stock, final concentration) and visualized under UV excitation on a transilluminator. Bands at ca. $370 \mathrm{bp}$ were excised using a sterile razor blade, and DNA was extracted from agarose plugs using Zymo gel recovery kits. Samples containing $25 \mathrm{ng}$ of purified PCR product were then restriction digested into terminal restriction fragments using HaeIII at $36^{\circ} \mathrm{C}$. Fragments were digested overnight $(12 \mathrm{~h})$ and reactions stopped by heating to $60^{\circ} \mathrm{C}$ for $5 \mathrm{~min}$. Pellets of DNA were then resuspended in $5 \mu \mathrm{l}$ deionised $\mathrm{H}_{2} \mathrm{O}$. Products from both ARISA and nifH-TRFLP were run for $5 \mathrm{~h}$ on an ABI 377XL automated sequencer with ABI 2500 bp FAMlabeled $2500 \mathrm{bp}$ standards. The sequencer electropherograms were then analyzed using ABI Genescan software.

Statistical analysis of ARISA and TRFLP data. Outputs from the ABI Genescan software were transferred to Microsoft Excel for subsequent analysis. Peaks less than 5 times the baseline fluorescence intensity were considered to be 'noise' and discarded. With this criterion, the practical detection limit for 1 operational taxonomic unit (OTU) was approximately $0.09 \%$ of the total amplified DNA. The area under each peak was expressed as a percentage of the total integrated area under the electropherogram. Simpson's indices $(D)$ were calculated manually using descriptions given in Legendre \& Legendre (1998) according to the following equation:

$$
D=\sum_{i=1}^{n}\left(p_{i}\right)^{2}
$$

Whole communities (i.e. all OTU each comprising $>0.09 \%$ of total amplified DNA) were compared by calculating the Jaccard Index of similarity and the Whittaker Index of similarity $\left(S_{\mathrm{w}}\right)$ using the following equations (Legendre \& Legendre 1998):

$$
\begin{gathered}
\text { Jaccard Index }=W\left(a_{1}+a_{2}-W\right)^{-1} \\
S_{\mathrm{w}}=1-\sum_{i=1}^{n} \frac{\left|\left(b_{i 1}-b_{i 2}\right)\right|}{2}
\end{gathered}
$$

where $p_{i}$ is the fraction of each peak of total integrated area, $W$ is the number of shared ITS peaks between assemblages 1 and 2, $a_{1}$ and $a_{2}$ are the total number of ITS or TRF lengths in assemblages 1 and 2, respectively, and where $b_{1}$ and $b_{2}$ are the percentage contributions to amplified DNA of the ith OTU or TRF in samples 1 and 2, respectively. These indices were scaled from 1 (completely identical) to 0 (completely different). Peaks were placed in bins at intervals $\pm 1 \mathrm{bp}$ for ITS lengths $<700 \mathrm{bp}, \pm 2.5$ for ITS lengths 700 to $1000 \mathrm{bp}$, and $\pm 5 \mathrm{bp}$ for ITS lengths $>1000 \mathrm{bp}$. To account for possible lumping and splitting of peaks, binning was repeated 10 times (maximum bin size), each time starting bins $+1 \mathrm{bp}$ from the preceding repetition (Hewson \& Fuhrman 2005). All Jaccard and Whittaker Indices indicated here represent the maximum similarity of those 10 bin frames. Agglomerative hierarchical cluster analysis was conducted using the XLStat (AddinSoft SARL) program via unweighted pair-group mean average method (UPGMA).

\section{RESULTS AND DISCUSSION}

Bacterial assemblage fingerprints, representing all taxa that comprise $>0.09 \%$ of total assemblage DNA (Hewson \& Fuhrman 2004) each contained 51 to 148 distinct OTU. The richness of fingerprints was higher than those reported in other fingerprinting studies using ARISA from pelagic (Hewson \& Fuhrman 2004) and sediment environments (Hewson et al. 2003); however, they were lower than estimates of richness using other methods (Torsvik et al. 2002). Previous research on coral-associated bacteria (using cloning and sequencing) has reported a high diversity of assemblages (Rohwer et al. 2002), and our results were consistent with previous studies that found higher richness and diversity in sediment assemblages than in overlying water (Hewson et al. 2003). Similarly, sediment diazotroph (i.e. nitrogen fixing) assemblage fingerprints contained 53 distinct OTU, which was more than detected using ARISA in other environments (e.g. rice paddies; Tan et al. 2003), but significantly lower than fingerprints from marine sediments and plankton that were determined by cloning and sequencing (which offer higher phylogenetic resolution than fingerprints) (Zehr et al. 1998, Burns et al. 2002). 
Bacterial assemblage fingerprints along the sediment transect shared $0.50 \pm 0.03$ Whittaker Index (mean $\pm \mathrm{SE}$ ) and $0.46 \pm 0.03$ Jaccard Index (mean $\pm \mathrm{SE}$, $\mathrm{n}=32$ pairwise comparisons); however, they displayed less similarity to the single water column fingerprint $(0.14 \pm 0.01$ Whittaker Index and $0.15 \pm 0.01$ Jaccard Index) (Fig. 2a). Samples collected $10 \mathrm{~cm}$ apart in Shark Bay had a Whittaker Index of 0.70 and a Jaccard Index of 0.60 . In a previous study of coastal bacterioplankton in Moreton Bay, which contains several different habitats (riverine, estuarine and open ocean), assemblages had an average similarity of $0.63 \pm 0.01$ Whittaker Index and $0.48 \pm 0.10$ Jaccard Index (Hew- son \& Fuhrman 2004). Diazotrophic assemblage fingerprints were also dissimilar to each other and shared a Jaccard Index of $0.38 \pm 0.05$ (mean \pm SE) (Fig. 2c). Four fingerprints from within the gutter zone (separated by ca. $30 \mathrm{~m}$ ) were similarly heterogeneous and shared a Whittaker Index of $0.43 \pm 0.03$ and a Jaccard Index of $0.45 \pm 0.04$ (mean $\pm \mathrm{SE}$ ). This may indicate that assemblages in coral reef flat sediments are patchy on scales of $\mathrm{cm}$, consistent with previous high-resolution studies of Pseudomonas spp. in soils (Cho \& Tiedje 2000). We believe this patchiness demonstrates that the habitat of coral reef flat sediments, along with homogeneous benthic primary productivity (Heil et al. 2004) and
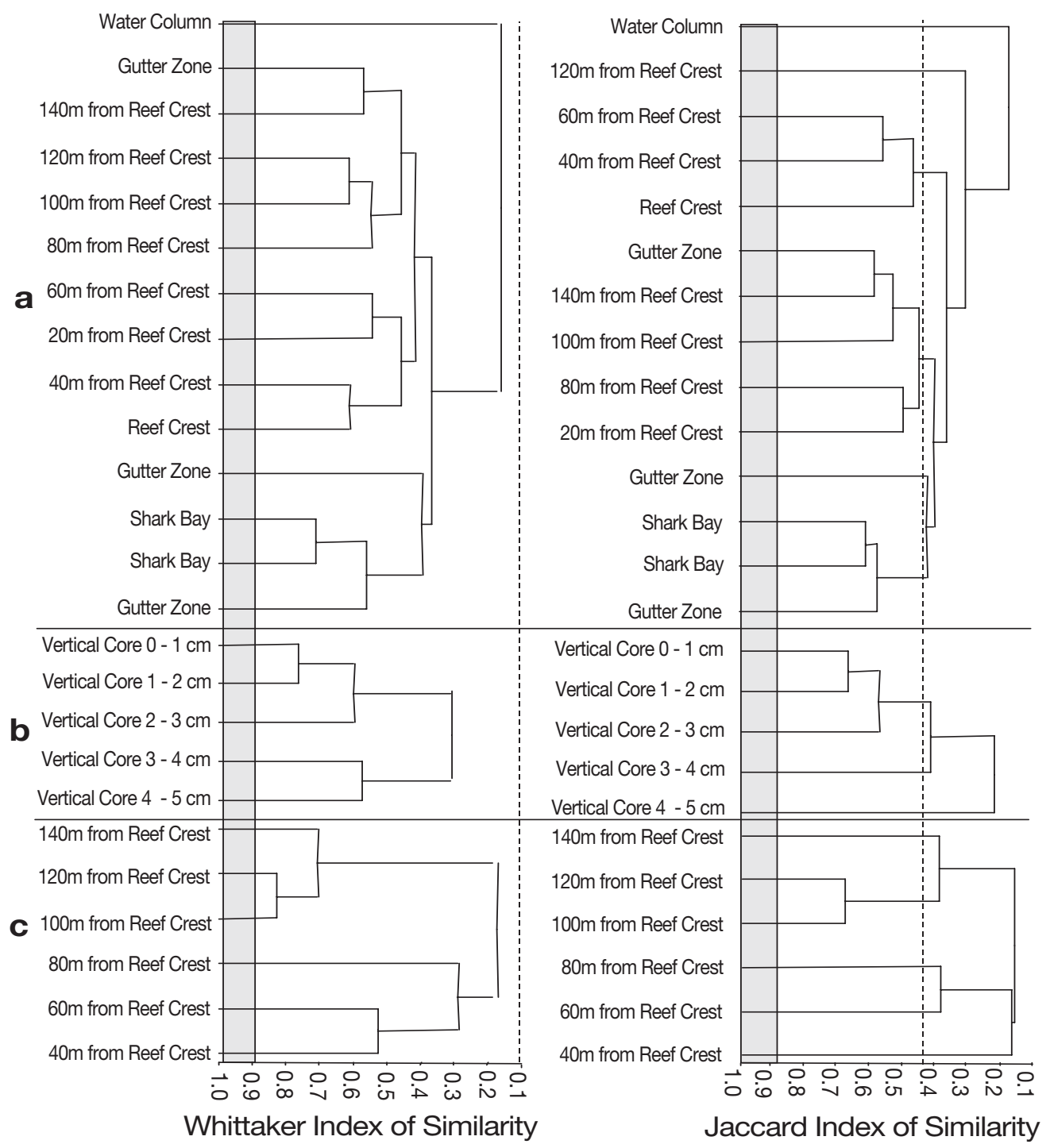

Fig. 2. Cluster analyses of reef flat microbial communities: (a) spatial and (b) vertical automated rRNA intergenic spacer analysis (ARISA) and (c) spatial nifH terminal restriction fragment length polymorphism (TRFLP) analyses. Clustering derived from the Whittaker Index of Similarity, the Jaccard Index, and unweighted pair-group-mean analysis. Light grey bar indicates average replicate fingerprint similarity. Dashed line on left indicates $95 \%$ of 1250 Monte Carlo generated random communities pairwise comparisons based upon random number of fragments (from 5 to 75), random fragment sizes from 400 to 1200 bp (i.e. similarity expected by chance alone), and random proportion of amplified DNA (exponentially distributed) (Hewson \& Fuhrman 2005) 


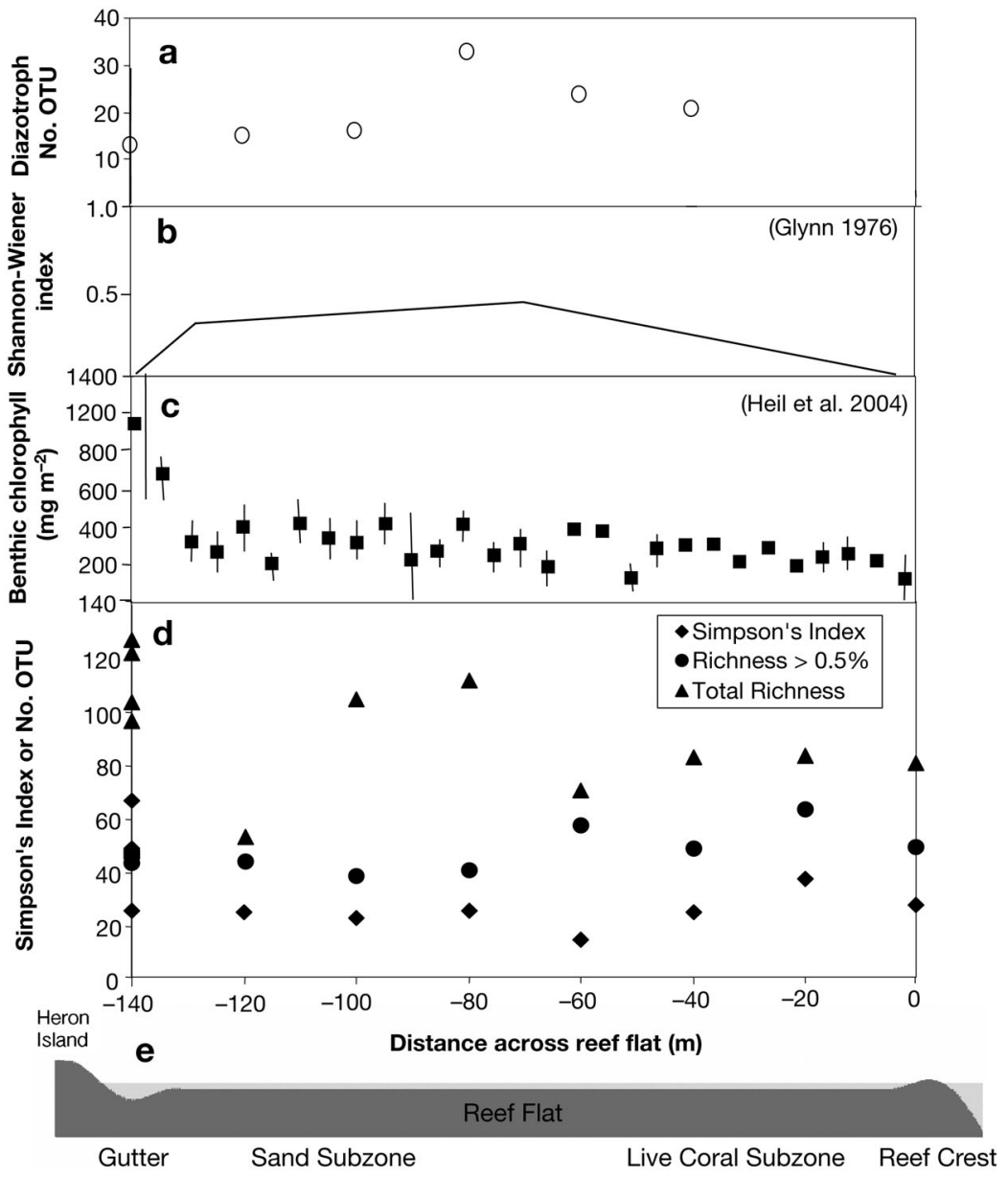

Fig. 3. Cross-reef flat richness of (a) nifH TRFLP fingerprints, (b) coral diversity redrawn from Glynn (1976), (c) benthic microalgal productivity (redrawn from Heil et al. 2004), and (d) diversity and richness of ARISA community fingerprints across (e) reef flat. Error bars indicate SE. OTU: operational taxonomic unit

On the Heron Reef, a scour zone or 'gutter', the result of breaching the reef crest to provide a boating channel in 1920 , is adjacent to the island $(-140 \mathrm{~m})$ and experiences strong currents between tides. Sediment microalgal productivity is highest in the gutter zone, which is believed to be due to greater sediment-surface boundary layer breakdown and concomitant enhanced nutrient availability compared to other reef flat locations (Heil et al. 2004). The richness of the whole bacterial assemblage fingerprints decreased from Heron Island to the reef crest, with the exception of the sample collected $-120 \mathrm{~m}$ from the reef crest (Pearson's correlation coefficient $(\mathrm{r})=-0.84, \mathrm{p}<0.01$ excluding $-120 \mathrm{~m}$ ) (Fig. 3). In contrast, the richness of each OTU that comprised $>0.5 \%$ of total amplified DNA (i.e. 'major' taxa) increased significantly from Heron Island to the reef crest ( $\mathrm{p}<0.05, \mathrm{n}=4$; Student's $t$-test comparing variance in -140 to $-80 \mathrm{~m}$ and -60 to $0 \mathrm{~m}$ ). All fingerprints from the gutter region and Shark Bay were of greater richness than fingerprints generated from -60 to $0 \mathrm{~m}$. This suggests that physical disturbance may select for a few OTU which are adapted to elevated water motion environments. Coral diversity is greatest when intermediately disturbed (Connell 1978), and is least diverse when high disturbance causes dominance by $r$-selected (i.e. fast

substratum type, may be subject to heterogeneous unmeasured factors (e.g. resource quality; Torsvik et al. 2002) which influence assemblage diversity.

Waves cause resuspension of sediments; however, resuspension varies with tides and location on the reef flat. This flux has various impacts upon microbial assemblages within sediments, and results e.g. in greater oxygen penetration, greater delivery of detritus, and removal of DOC and nutrients from sediments. Wave energy represents physical energy flux (e.g. water motion) that in turn creates a gradient of disturbance from reef crest to island. Areas closer to the reef crest experience physical energy primarily in the form of wave motion, while those closer to the island experience energy mainly as laminar flow. Since laminar flow of water (currents) probably does not disturb sediments as greatly as wave action, or at least does so uniformly over small scales, sediment microbial assemblages near the reef crest experience greater physical disturbance than those closer to Heron Island. growing, opportunistic) species (e.g. Pocillopora spp.). Connell's (1978) study confirmed earlier work (Glynn 1976) that demonstrated high coral diversity away from the high water motion reef crests, but dominance by Pocillopora spp. on the crest itself. Our results are consistent with work on scleractinian corals, as bacterial fingerprints contained a higher relative abundance of some bacteria (i.e. 'dominant' bacteria) that caused an overall lower diversity index at the location of the highest water motion regime. The fingerprint Simpson's Index was moderately higher $-20 \mathrm{~m}$ from the reef crest, which may reflect that this zone experiences intermediate disturbance (Fig. 3).

Physical energy flux potentially shapes bacterial assemblages. However, biotic interactions may play a more important role in shaping sediment bacterial assemblages. Since benthic microalgal photosynthesis corresponds with elevated bacterial production on the reef flat (Moriarty \& Hansen 1990), benthic microalgal productivity probably plays an important role in determining 


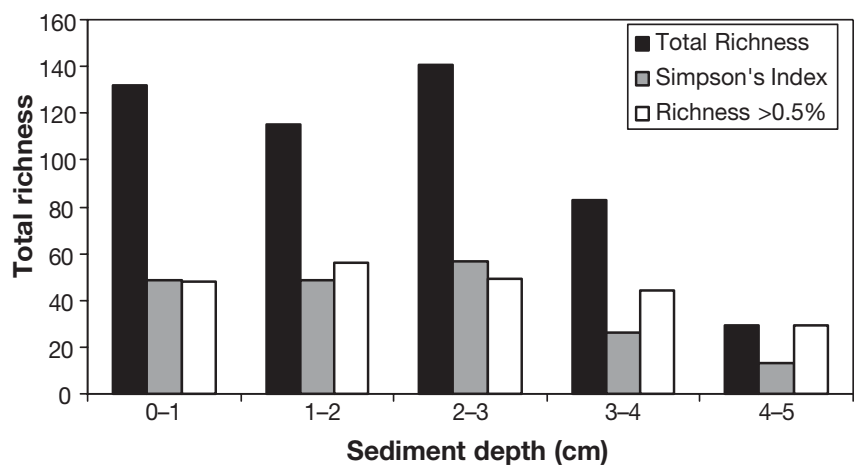

Fig. 4. ARISA fingerprint richness and diversity in vertical profile at 1 station in the gutter zone

sediment bacterial assemblages. Unfortunately, since productivity was elevated only in the gutter (Heil et al. 2004), we were unable to collect sufficient samples to examine this relationship.

Two biotic factors have been demonstrated to influence bacterial communities at Heron Island and elsewhere: these are (1) the chemical environment (redox state and electon acceptor/donor speciation) of sediments (a consequence of biological activities), and (2) grazing by macrofauna (Moriarty et al. 1985). Since there is no appreciable cross-reef flat gradient in nutrient availability, as reflected by nutrient limitation to all benthic microalgae (Heil et al. 2004), geochemical gradients are primarily vertical. We investigated the relationships among assemblage fingerprints in vertical profile at a single location in the gutter zone. Richness of bacterial OTU demonstrated a subsurface maximum, which perhaps corresponded to the oxic/anoxic boundary (Fig. 4). Assemblages closer to the surface (0 to $3 \mathrm{~cm}$ ) were more similar to each other (Whittaker Index: $0.78 \pm 0.12 ;$ Jaccard Index $0.74 \pm 0.07$, mean \pm SE) than to deeper communities (Whittaker Index: $0.35 \pm 0.03$; Jaccard Index of $0.29 \pm 0.06$ ) (Fig. 2b).

The tropical sea cucumber Holothuria atra has been demonstrated to cause significant stimulation of both bacterial (Moriarty et al. 1985) and benthic microalgal (Uthicke 2001) production via grazing activities. These deposit-feeding organisms are most abundant close to Heron Island and are believed to graze a large percentage of total reef flat area daily (Moriarty et al. 1985). We collected sediments within $2 \mathrm{~cm}$ of the mouth of 2 individuals and also collected unconsolidated fecal pellets. Samples collected within $10 \mathrm{~cm}$ of each other (i.e. a similar distance to that between food and feces of $H$. atra) elsewhere on the reef flat (Shark Bay) shared a Whittaker Index of 0.70 and a Jaccard Index of 0.60 , therefore we expected differences between food sediment and holothurian feces to reflect grazing impact. Assemblage fingerprints of bacteria in fecal pellets and surrounding sediments shared a Whittaker Index of
$0.51 \pm 0.10$ and a Jaccard Index of $0.40 \pm 0.14$ (mean \pm $\mathrm{SE}$ ), indicating that grazing impact could not be distinguished from the substantial ambient small-scale variability.

Our results relied on assemblage fingerprints, for which there may be questions regarding the applicability of this approach to quantitative ecological studies. Assemblage fingerprinting techniques are not perfect due to biases inherent in the PCR (Suzuki \& Giovannoni 1996), variation in operon copy number (Klappenbach et al. 2000), and differences in cell extractability among taxa (Polz \& Cavanaugh 1998). However, fingerprints are reproducible and allow clear differences among communities to be observed (Hewson \& Fuhrman 2004). Furthermore, a recent ARISA study of OTU within bacterioplankton assemblage fingerprints corresponding to Prochlorococcus spp. compared remarkably favorably to flow cytometric enumeration $\left(\mathrm{r}^{2}=0.86\right)$ from $4 \mathrm{yr}$ of monthly time series data from the San Pedro Ocean Time Series (Brown et al. 2005). In this study, we used fingerprinting techniques to compare bacterial communities in different samples, and our conclusions did not fully rely on relative abundance data and were also supported by presence/absence data (Jaccard Index changes).

Coral reef flat sediment bacterial assemblages showed variability among sites both in terms of common (i.e. $>1 \%$ of total amplified DNA in fingerprints) and rare ( $<1 \%$ of total amplified DNA) bacterial OTU, and were therefore patchy when entire assemblage fingerprints were examined. While we cannot exclude the effects of unmeasured variables upon the structure of sediment bacterial assemblages, this study demonstrated that patterns of assemblage variability are consistent with gradients in physical energy flux. Finally, this study demonstrated the utility of fingerprinting techniques for comparing sediment bacterial assemblages.

Acknowledgements. We thank D. Logan, C. Bagnato and T. Hughes at Heron Island Research Station and J. Udy and S. Albert at the University of Queensland for assistance and equipment supply. We also thank D. Capone, J. Steele, M. Schwalbach, X. Hernandez, M. Brown and P. Countway at USC for assistance in the lab. Helpful comments on an early manuscript draft were provided by S. Costanzo. Samples were collected under permit G02/4358.1 from the Great Barrier Reef Marine Park Authority. This work was supported by NSF Grant MCB0084231 awarded to J.A.F. This work is in partial fulfillment of a PhD by I.H.

\section{LITERATURE CITED}

Beijerinck M (1913) De infusies en de ontdekking der backterien. Muller, Amsterdam

Brown MV, Schwalbach MS, Hewson I, Fuhrman JA (2005) 
Coupling 16S-ITS rDNA clone libraries and ARISA to show marine microbial diversity: development and application to a time series. Environ Microbiol 7:1466-1479

Burns JA, Zehr JP, Capone DG (2002) Nitrogen-fixing phylotypes of Chesapeake Bay and Neuse River estuary sediments. Microbiol Ecol 44:336-343

Capone DG (1996) Coral reef ecosystems in the context of the marine nitrogen cycle. In: Bjork M, Semesi AK, Pedersen M, Bergman B (eds) Current trends in marine botanical research in the East African region. Ord \& Vetande, Uppsala, p 61-76

Cho JC, Tiedje JM (2000) Pseudomonas strains in soil. Appl Environ Microbiol 66:5448-5456

Connell JH (1978) Diversity in tropical rainforests and coral reefs. Science 199:1304-1310

Fisher MM, Triplett EW (1999) Automated approach for ribosomal intergenic spacer analysis of microbial diversity and its application to freshwater bacterial communities. Appl Environ Microbiol 65:4630-4836

Fuhrman JA, Davis AA (1997) Widespread Archaea and novel bacteria from the deep sea as shown by 16S rRNA gene sequences. Mar Ecol Prog Ser 150:275-285

Giovannoni SJ, Britschgi TB, Moyer CL, Field KG (1990) Genetic diversity in Sargasso Sea bacterioplankton. Nature 345:60-63

Glynn PW (1976) Some physical and biological determinants of coral community structure in the Eastern Pacific. Ecol Monogr 46:431-456

Heil CA, Chaston KA, Jones A, Bird P, Longstaff B, Costanzo $\mathrm{S}$, Dennison WC (2004) Benthic microalgae in coral reef sediments of the southern Great Barrier Reef, Australia. Coral Reefs 23:336-343

Hewson I, Fuhrman JA (2004) Bacterioplankton species richness and diversity along an estuarine gradient in Moreton Bay, Australia. Appl Environ Microbiol 70:3425-3433

Hewson I, Fuhrman JA (2005) Improved strategy for comparing microbial assemblage fingerprints. Microb Ecol DOI: 10.1007/s00248-005-0144-9

Hewson I, Vargo GA, Fuhrman JA (2003) Bacterial diversity in shallow oligotrophic marine benthos and overlying waters: effects of virus infection, containment and nutrient enrichment. Microb Ecol 46:322-336

Hughes TP, Baird AH, Bellwood DR, Card M and 13 others (2003) Climate change, human impacts, and the resilience of coral reefs. Science 301:929-933

Klappenbach JL, Dunbar JM, Schmidt TM (2000) rRNA operon copy number reflects ecological strategies of bacteria. Appl Environ Microbiol 66:1328-1333

Legendre P, Legendre L (1998) Numerical ecology. Elsevier, Amsterdam

Moriarty DJW, Hansen JA (1990) Productivity and growth

Editorial responsibility: Fereidoun Rassoulzadegan (Contributing Editor), Villefranche-sur-Mer, France rates of coral reef bacteria on hard calcareous substrated and in sandy sediments in summer. Aust J Mar Freshw Res 41:785-794

Moriarty DJW, Pollard PC, Hunt WG, Moriarty CM, Wassenberg TG (1985) Productivity of bacteria and microalgae and the effect of grazing by holothurians in sediments on a coral reef flat. Mar Biol 85:293-300

Morris RM, Rappé M, Connon SA, Vergin KL, Siebold WA, Carlson CA, Giovannoni SJ (2002) SAR11 clade dominated ocean surface bacterioplankton communities. Nature 420:806-810

Polz MF, Cavanaugh CM (1998) Bias in template-to-product ratios in multitemplate PCR. Appl Environ Microbiol 64: $3724-3730$

Rasheed M, Wild C, Franke U, Huettel M (2004) Benthic photosynthesis and oxygen consumption in permeable carbonate sediments at Heron Island, Great Barrier Reef, Australia. Estuar Coast Shelf Sci 59:139-150

Rohwer F, Seguritan V, Azam F, Knowlton N (2002) Diversity and distribution of coral-associated bacteria. Mar Ecol Prog Ser 243:1-10

Suzuki MT, Giovannoni SJ (1996) Bias caused by template annealing in the amplification of mixtures of 16S rRNA genes by PCR. Appl Environ Microbiol 62:625-630

Tan Z, Hurek T, Reinhold-Hurek B (2003) Effect of N-fertilization, plant genotype and environmental conditions on nifH gene pools in roots of rice. Environ Microbiol 5:1009-1015

Torsvik V, Ovreas L, Thingstad TF (2002) Prokaryotic diversity - magnitude, dynamics and controlling factors. Science 296:1064-1066

Uthicke S (2001) Nutrient regeneration by abundant coral reef holothurians. J Exp Mar Biol Ecol 265:153-170

Venter JC, Remington K, Heidelberg JF, Halpern AL and 19 others (2004) Environmental genome shotgun sequencing of the Sargasso Sea. Science 304:66-74

Webster G, Parkes RJ, Fry JC, Weightman AJ (2004) Widespread occurrence of a novel division of bacteria identified by $16 \mathrm{~S}$ rRNA gene sequences originally found in deep marine sediments. Appl Environ Microbiol 70:5708-5713

Widmer F, Schafer BT, Porteous LA, Seidler RJ (1999) Analysis of nifH gene pool complexity in soil and litter at a Douglas fir forest site in the Oregon Cascade Mountain Range. Appl Environ Microbiol 65:374-380

Wild C, Huettel M, Klueter A, Kremb SG, Rasheed MYM, Jorgensen BB (2004) Coral mucus functions as an energy carrier and particle trap in the reef ecosystem. Nature 428: 66-69

Zehr JP, Mellon MT, Zani S (1998) New nitrogen-fixing microorganisms detected in oligotrophic oceans by the amplification of nitrogenase (nifH) genes. Appl Environ Microbiol 64:3444-3450

Submitted: May 25, 2005; Accepted: August 5, 2005

Proofs received from author(s): November 29, 2005 